\title{
Polyketide-Derived Alkaloids and Anthraquinones in Aloe Plants and Cell Cultures
}

\section{Hannu Hotti, Suvi T. Häkkinen, Tuulikki Seppänen-Laakso and Heiko Rischer*}

\author{
VTT Technical Research Centre of Finland, Espoo, Finland
}

\begin{abstract}
Plants of the genus Aloe $\mathrm{L}$ are known to be rich in secondary metabolites such as anthraquinones and flavonoids. Only twelve out of about 400 species contain piperidine alkaloids. Representative species of this group, Aloe gariepensis Pillans, A. globuligemma Pole Evans and $A$. viguieri $\mathrm{H}$. Perrier were cultivated in vitro and investigated for their polyketide-derived content using gas chromatography-mass spectrometry. All three species contained hemlock alkaloids in different amounts either in leaves or roots but $A$. globuligemma and $A$. viguieri accumulated $\mathrm{N}$-methylconiine, an alkaloid not previously reported from any Aloe species. Micropropagation of A. viguieri was investigated using statistical experimental design. A mother plant produced up to five plantlets of good quality on Murashige and Skoog (MS) medium [1] with $0.25 \mathrm{mg} \mathrm{L}^{-1} 6$-Benzyl Aminopurine (BA) and $0.4 \mathrm{mg}$ $\mathrm{L}^{-1}$ Naphthalene Acetic Acid (NAA). Calli of $A$. gariepensis and $A$. viguieri explants were induced on MS medium containing a combination of $10.0 \mathrm{mg} \mathrm{L}^{-1} \mathrm{NAA}$ and $0.2 \mathrm{mg} \mathrm{L}^{-1} \mathrm{BA}$ and $6.0 \mathrm{mg} \mathrm{L}^{-1}$ 2,4-Dichlorophenoxyacetic acid (2,4-D), respectively. Long-term callus maintenance was facilitated on MS with $1.0 \mathrm{mg} \mathrm{L}^{-1} 2,4-\mathrm{D}$ for both species. The callus of neither species contained piperidine alkaloids after elicitation with chitosan or salicylic acid. After elicitation with chitosan or salicylic acid the suspension cultures of both Aloe species contained anthraquinones, chrysophanol and chrysarobin, the latter representing a new record for the genus.
\end{abstract}

Keywords

Alkaloids, Anthraquinones, Aloe, Coniine, Callus, Micropropagation, Polyketides

\section{Abbreviations}

2,4-D: 2,4-Dichlorophenoxyacetic acid; BA: 6-Benzyl Aminopurine; CCF: Central Composite Face; DW: Dry Weight; FW: Fresh Weight; GC-MS: Gas Chromatography-Mass Spectrometry; KIN: Kinetin; MS: Murashige and Skoog medium; NAA: Naphthalene Acetic Acid; OKS: Octaketide Synthase; PKS: Polyketide Synthase; PVP: Polyvinylpolypyrrolidone

\section{Introduction}

The genus Aloe L., Xanthorrhoeaceae, comprises about 400 species native to Sub-Saharan Africa, the Arabian Peninsula, and Madagascar [2]. In many cultures, Aloe, especially A. vera, has long been used as a traditional medicine. The aloe products from different parts of the plant, which include the latex, gel, and whole leaf, have been used as laxatives, in creams for skin ointments, and as a treatment for several diseases. Members of the genus exhibit a wide range of secondary metabolites of medicinal value, for example, aloe emodin from A. ferox [3] and barbaloin (aloin A) from A. vera [4]. Remarkably many compounds in Aloe are derived from polyketides (Figure 1A). Type III Polyketide Synthases (PKS) [5] are the key condensing enzymes in these pathways.

Anthraquinones (Figure 1B) are a class of natural compounds with a planar three aromatic ring structure and two keto groups at the 9 and 10-positions [6]. Aloe anthraquinone biosynthesis is catalyzed by Octaketide Synthase (OKS) from one acetyl-CoA and seven malonyl-CoAs [7]. Anthraquinones are found in different genera including Aloe [8], Rheum, Rumex, Rhamnus and

\footnotetext{
*Corresponding author: Heiko Rischer, VTT Technical Research Centre of Finland Ltd, PO Box 1000, Espoo FI02044 VTT, Finland, Tel: 358-20-722-4461, Fax: 358-20722-7071, E-mail: heiko.rischer@vtt.fi
}

Received: June 29, 2017; Accepted: August 14, 2017; Published online: August 17, 2017

Citation: Hotti H, Häkkinen ST, Laakso TS, et al. (2017) Polyketide-Derived Alkaloids and Anthraquinones in Aloe Plants and Cell Cultures. J Plant Biotechnol Res 1(1):1-15

Copyright: (c) $2017 \mathrm{Hotti} \mathrm{H}$, et al. This is an open-access article distributed under the terms of the Creative Commons Attribution License, which permits unrestricted use, distribution, and reproduction in any medium, provided the original author and source are credited. 
A)

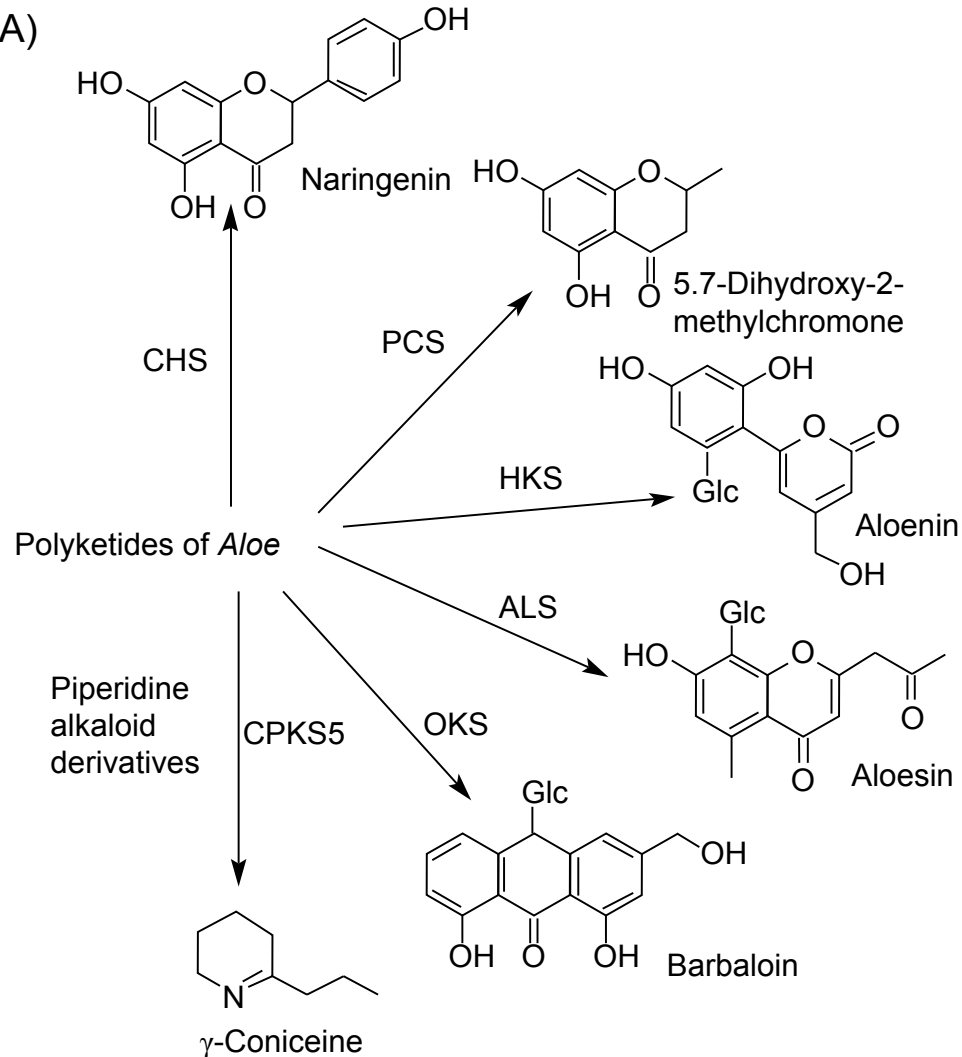

C)<smiles>CCCC1CCC(O)CN1</smiles><smiles>CCCC1CCCCN1C</smiles><smiles>CCCC1CCCC[N+]1(C)C</smiles>

$N$-methylconiine

B)<smiles>Cc1cc(O)c2c(O)c3c(O)cccc3cc2c1</smiles>

Chrysarobin<smiles>[R]C1=CC2C(=O)c3cc([R])cc(O)c3C(=O)C2C(O)=C1</smiles>

Aloe emodin $\mathrm{H} \quad \mathrm{CH}_{2} \mathrm{OH}$

Chrysophanol $\mathrm{H} \quad \mathrm{CH}_{3}$

Rhein $\mathrm{H} \quad \mathrm{COOH}$

Emodin $\mathrm{OH} \quad \mathrm{CH}_{3}$

Figure 1: Aloe metabolites A) Known polyketide derivatives. CHS: Chalcone Synthase; PCS: Pentaketide Chromone Synthase; HKS: Hexaketide Synthase; ALS: Aloesin Synthase; OKS: Octaketide Synthase; CPKS5: Conium Polyketide Synthase 5; B) Anthraquinones; C) Piperidine alkaloids [10-12].

Senna [9]. The compounds have multiple uses in textile dying, paints, foods, cosmetics, and pharmaceuticals with diverse functions such as anticancer, laxative and anti-inflammatory [6].

Only a limited number of Aloe species contain alkaloids including the purines hypoxanthine and xanthine from A. ferox [3]. The tyramine-derived phenylethylamines are found in 18 Aloe species [10]. Hitherto twelve Aloe species have been reported to contain piperidine alkaloids (Table 1) [10-12] including coniine, $\gamma$-coniceine, and conhydrine (Figure 1C). Interestingly, these alkaloids are otherwise only known from phylogenetically distant dicotyledonous plants, i.e. poison hemlock (Conium maculatum L.) and pitcher plants (Sarracenia spp.) $[13,14]$. So far the biosynthesis of coniine alkaloids has only been investigated in poison hemlock. Theoretically, the carbon backbone of the alkaloids in Aloe could be either a tetraketide polyketide derivative $[15,16]$ or a triketide [17]. The nitrogen of L-alanine is subsequently introduced in a transaminase-catalyzed reaction [18] followed by a non-enzymatic cyclization to form $\gamma$-coniceine [19]. Coniine formation from $\gamma$-coniceine is finally catalyzed by NADPH-dependent $\gamma$-coniceine reductase [20]. There are reports that poisonous aloes, among them A. globuligemma, have been administered as medicines, causing deaths in rural Africa [21]. Parry, et al. [22] studied the toxicity of A. globuligemma due to its use as a traditional herbal medicine in Zimbabwe. The crude extract is toxic, with an $\mathrm{LD}_{50}$ of less than $250 \mathrm{mg} \mathrm{kg}^{-1}$ in mice, which exhibited symptoms similar to those of poison hemlock intoxication. In some cases, toxic and beneficial aloes have been confused due to misidentification [23].

The biotechnology of Aloe is underdeveloped and underutilized [24], although many species are already endangered in their natural habitats. Commercial and research interest has driven the development of micro- 
Citation: Hotti H, Häkkinen ST, Laakso TS, et al. (2017) Polyketide-Derived Alkaloids and Anthraquinones in Aloe Plants and Cell Cultures. J Plant Biotechnol Res 1(1):1-15

Table 1: Hemlock alkaloids reported from Aloe [10-12].

\section{Species}

A. ballyii Reynolds

A. deltoideodonta Baker

A. descoingsii Reynolds

A. gariepensis Pillans

A. globuligemma Pole Evans

A. gracilicaulis Reynolds \& P.R.O. Bally

A. ibitiensis Perrier

A. krapholiana Marloth

A. ortholopha Christian \& Milne-Redh

A. ruspoliana Baker

A. sabaea Schweinf. (syn. A. gillilandii Reynolds)

A. viguieri Perrier

\section{Alkaloids}

$\mathrm{Y}$-coniceine, conhydrinone

$\mathrm{Y}$-coniceine, a trace of pseudoconhydrine

Coniine, conhydrine

$\mathrm{Y}$-coniceine, conhydrine

Coniine, conhydrine

$\mathrm{Y}$-coniceine

$\mathrm{Y}$-coniceine

Coniine, conhydrine

Coniine, conhydrine

$\mathrm{Y}$-coniceine

$\mathrm{Y}$-coniceine, coniine, $\mathrm{N}, \mathrm{N}$-dimethylconiine

Coniine, a trace of $\mathrm{Y}$-coniceine

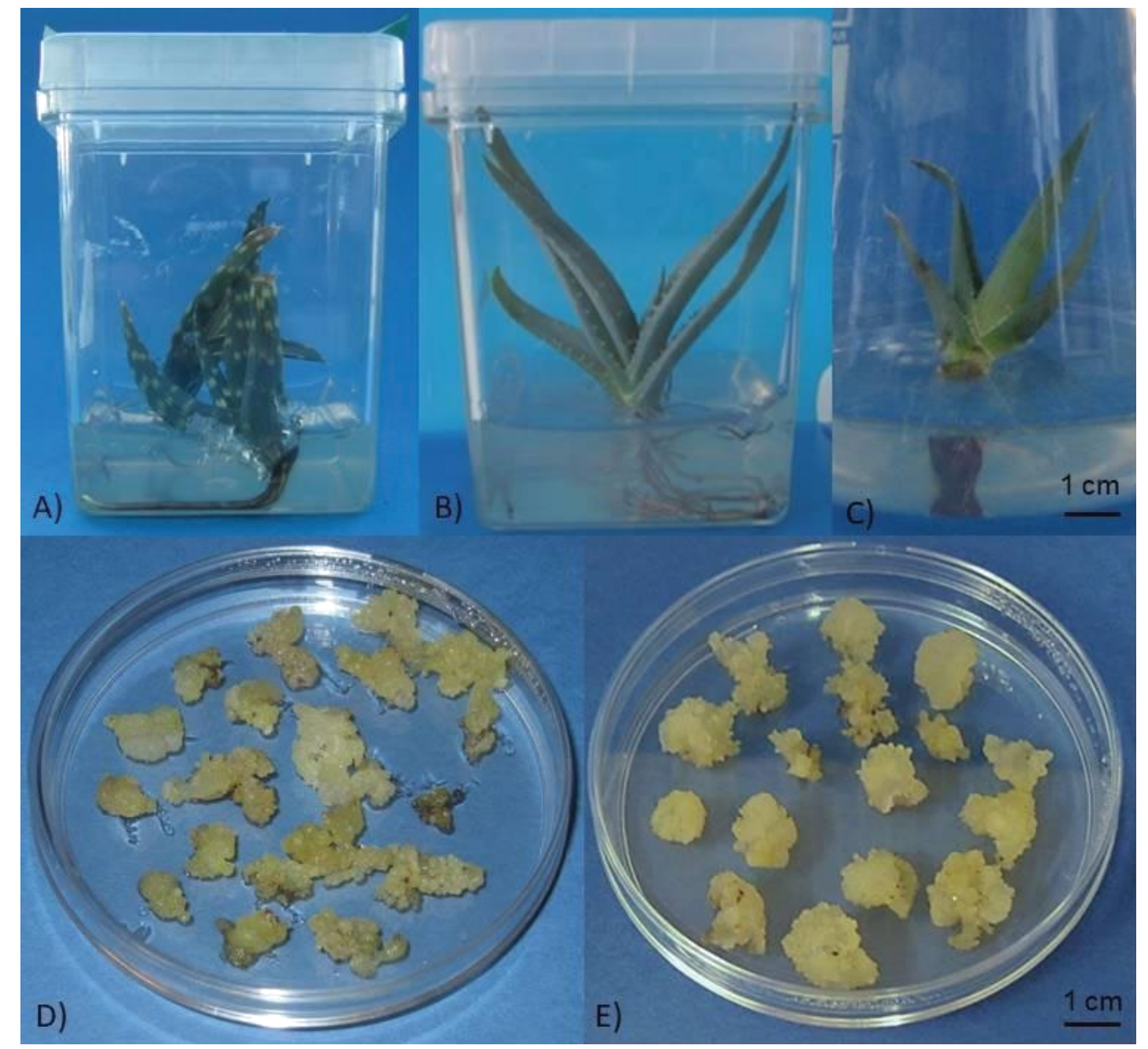

Figure 2: Plantlets of A) A. gariepensis; B) A. globuligemma; C) A. viguieri; and Callus from D) A. gariepensis and E) A. viguieri.

propagation methods for a certain number of species [25]. A. vera (syn. A. barbadensis) is certainly the most prominent example due to its economic importance [26], and A. polyphylla is a representative example of an endangered species [27]. It must be emphasized that species-specific micropropagation protocols are required. Some of these methods proceed via callus formation [24], but callus cultures have also been specifically initiated for genetic transformation [28] and the production of certain compounds [29]. Callus formation has been reported for $A$. arborescens [30], A. bellatura [31], A. ferox [32], A. polyphylla [33], A. pretoriensis [34], A. saponaria [35] and A. vera [36]. Piperidine alkaloid-producing Aloe species have hitherto not attracted any attention in this respect. 
Here we report the in vitro cultivation of A. gariepensis, A. globuligemma and A. viguieri. Greenhouse-grown specimens of all three species have been reported to contain hemlock alkaloids $[10,11]$. We focused on establishing micropropagation for A. viguieri and cell culture development together with elicitation for A. viguieri and $A$. gariepensis, which constitute representatives for poison aloes, while monitoring alkaloid and other polyketide-derived compounds in order to provide a basis for biochemical investigations. Interestingly, one piperidine alkaloid and one anthraquinone, respectively, were detected and identified in Aloe for the first time, illustrating the potential of Aloe cell cultures for further compound discoveries.

\section{Materials and Methods}

\section{Plant material}

Aloe gariepensis Pillans (Figure 2A), A. globuligemma Pole Evans (Figure 2B), and A. viguieri H. Perrier (Figure 2C) seeds were obtained from B \& T World Seeds (Paguignan, France). Poison hemlock (Conium maculatum L.) seeds were collected in Helsinki, Finland.

Poison hemlock and barley were grown under greenhouse conditions at $20{ }^{\circ} \mathrm{C}, 60 \%$ humidity, and a $16 / 8 \mathrm{~h}$ photoperiod. The potting soil consisted of half vermiculite and half peat (Kekkilä Oy, Vantaa, Finland).

\section{Surface sterilization and in vitro germination}

A. gariepensis $(\mathrm{n}=10)$, A. globuligemma $(\mathrm{n}=10)$ and A. viguieri $(\mathrm{n}=5)$ seeds were surface sterilized by dipping them into $70 \%$ ethanol for three minutes, followed by immersion in $2 \%$ sodium hypochlorite containing a drop of Tween-20 (Sigma-Aldrich, Lyon, France) for 20 minutes and washing three times with sterile ultrapure water. Seeds were placed on Murashige and Skoog (MS) medium [1] (Duchefa Biochemie B.V., Haarlem, the Netherlands) with $3.0 \mathrm{~g} \mathrm{~L}^{-1}$ gelrite at $\mathrm{pH} 5.8$ for germination. The in vitro plants were kept on MS medium without hormones and transferred to fresh medium every second month.

\section{Micropropagation}

A. viguieri plants were grown on $50 \mathrm{~mL}$ MS medium with $30.0 \mathrm{~g} \mathrm{~L}^{-1}$ sucrose and $3.0 \mathrm{~g} \mathrm{~L}^{-1}$ gelrite in $250 \mathrm{~mL}$ wide neck Erlenmeyer flasks. Altogether 28 plants were used in the experiments. The medium was supplemented with 0.10-2.00 $\mathrm{mg} \mathrm{L}^{-1}$ Naphthalene Acetic Acid (NAA) and 0.06-4.00 $\mathrm{mg} \mathrm{L}^{-1}$ 6-Benzyl Aminopurine (BA) (Sigma-Aldrich, St. Louis, MO, USA). Effects were recorded after 4,5 , and 6 weeks.

Experiments and data analyses were performed with the experimental design software MODDE 9.0 (Umet- rics, Malmö, Sweden). To minimize the necessary number of plants, the Central Composite Face (CCF) design was applied to investigate effects of different variables on the number of initiated plantlets. In CCF the studied parameters are within a certain distance of the central point, and to determine repeatability the central point was measured in triplicate. Studied factors were initially: $0.06,0.16$ and $0.25 \mathrm{mg} \mathrm{L}^{-1} \mathrm{BA}$ and $0.1,0.25$ and $0.4 \mathrm{mg} \mathrm{L}^{-1}$ NAA after four, five and six weeks. The equation for the polynomial model is:

$$
\begin{aligned}
& y=-6.59524+27.5048 \times x_{1}+13.7619 \times x_{2}+1.71429 \times x_{3} \\
& +51.4286\left(x_{3}\right)^{2}-4.19048 \times\left(x_{1} \times x_{3}\right)-7.38095 \times\left(x_{2} \times x_{3}\right)
\end{aligned}
$$

Where $\mathrm{x}_{1}=[\mathrm{BA}], \mathrm{x}_{2}=[\mathrm{NAA}]$ and $\mathrm{x}_{3}=$ [time]. In the follow-up experiment, the parameters were: $0.25,2.13$, $4.0 \mathrm{mg} \mathrm{L}^{-1} \mathrm{BA}$ and $0.4,1.2,2.0 \mathrm{mg} \mathrm{L}^{-1} \mathrm{NAA}$, with monitoring after four, five and six weeks.

\section{Callus initiation and maintenance}

Explants were derived from A. gariepensis and A. viguieri in vitro plants. Leaves or stems were cut into pieces and were placed in Petri dishes $(\varnothing 9 \mathrm{~cm} ; 5$ pieces/plate) containing MS medium with $1.0 \mathrm{~g} \mathrm{~L}^{-1}$ Polyvinylpolypyrrolidone (PVP) (average mol wt 40,000, Sigma-Aldrich, St. Louis, MO, USA) [36], $18.34 \mathrm{mg} \mathrm{L}^{-1}$ adenine and $100.0 \mathrm{mg} \mathrm{L}^{-1} \mathrm{~L}$-ascorbic acid (Sigma-Aldrich, Shanghai, China) [24]. The hormone combinations were $10.0 \mathrm{mg} \mathrm{L}^{-1} \mathrm{NAA}$ and $0.2 \mathrm{mg} \mathrm{L}^{-1} \mathrm{BA}$ [29] or only $6.0 \mathrm{mg}$ $\mathrm{L}^{-1}$ 2,4-dichlorophenoxyacetic acid (2,4-D) (Sigma-Aldrich, St. Louis, MO, USA) [24]. The callus initiation plates were incubated in a growth chamber (Sanyo versatile environmental test chamber, Sanyo Electric Co., Ltd., Takamatsu, Japan) with a $16 / 8 \mathrm{~h}$ photoperiod at $25{ }^{\circ} \mathrm{C} / 23{ }^{\circ} \mathrm{C}$ (day/night) for 50 days. In the beginning, the formed calli were kept on the initiation media with the same hormone combinations, in the dark and were transferred every week. Six weeks after initiation, callus was transferred to MS supplemented with $2.0 \mathrm{mg} \mathrm{L}^{-1} 2,4$ $\mathrm{D}$ without PVP, adenine, and ascorbic acid. Nine weeks later callus cultures were transferred to MS medium with $1.0 \mathrm{mg} \mathrm{L}^{-1} 2,4$-D. For maintenance fast growing and non hyper hydrated callus was selected and sub-cultured every third week while kept in darkness at $25^{\circ} \mathrm{C}$.

\section{Growth curve}

The Fresh Weight (FW) of calli was recorded for three weeks to choose cell lines for further experimentation. Three lines of both species were selected and labeled as A-C (A. gariepensis) and D-E (A. viguieri) based on vigorous growth and without browning or excessive leaching of phenolics into the medium. For each selected line 12 pieces were weighed at the beginning of cultivation and then once every week. The average FW increase of 
the calli was calculated for each line. Statistical analyses of callus growth were performed with One-way ANOVA and Tamhane's T2 using IBM SPSS Statistics software (Version 22).

The growth curves for suspension cultivations were performed in sterilized $125 \mathrm{~mL}$ glass Erlenmeyer flasks containing $25 \mathrm{~mL}$ MS medium with $1.0 \mathrm{mg} \mathrm{L}^{-1} 2,4-\mathrm{D}$. Inoculum with biweekly sub-cultured cells of lines $\mathrm{C}$ and $\mathrm{D}$ was added to each flask at a concentration of $50.0 \mathrm{~g}$ $\mathrm{L}^{-1} \pm 1.0 \mathrm{~g} \mathrm{~L}^{-1} \mathrm{FW}$. At each time point, a series of three replicates was investigated (in total 33 flasks for each cell line). Flasks were placed on an orbital shaker (130 rpm) at $24{ }^{\circ} \mathrm{C}$ and cultured in darkness. Conductivity and $\mathrm{pH}$ of the medium, as well as the FW and Dry Weights (DW) of the cell mass, were determined for all replicates at each time point.

\section{Elicitation}

Individual elicitors were added to cell lines $\mathrm{C}$ and $\mathrm{D}$ to test secondary metabolite production. Erlenmeyer flasks $(125 \mathrm{~mL})$ containing $25 \mathrm{~mL}$ MS medium with $1.0 \mathrm{mg} \mathrm{L}^{-1}$ 2,4-D were inoculated with $50.0 \mathrm{~g} \mathrm{~L}^{-1} \pm 1.0 \mathrm{~g} \mathrm{~L}^{-1} \mathrm{FW}$ of biweekly subcultured cells. At day 8 and day 14 for cell lines $\mathrm{C}$ and $\mathrm{D}$, respectively, elicitors were added at the concentrations $110 \mathrm{mg} \mathrm{L}^{-1}$ for chitosan (Sigma-Aldrich, St. Louis, MO, USA) [37] and $138 \mathrm{mg} \mathrm{L}^{-1}$ for salicylic acid (Sigma-Aldrich, St. Louis, MO, US) [38]. Cultures were harvested on the $1^{\text {st }}, 3^{\text {rd }}$ and $5^{\text {th }}$ day after elicitation [39]. Chitosan stock solution of $0.1 \mathrm{M}$ acetic acid in water at pH 5.0 was prepared according to Sevón, et al. [40]. Adverse effects of acetic acid to cell lines $\mathrm{C}$ and $\mathrm{D}$ was tested in an additional flask at the highest volume tested in the elicitor experiment. Samples treated with stock solution solvent were collected after one, three and five days. Cells and growth medium were separated by vacuum filtration and cells were lyophilized.

\section{Metabolite extraction}

Freeze-dried plant material $(100 \pm 10 \mathrm{mg})$ was used for secondary metabolite extraction according to Häkkinen, et al. [41]. Lipids were removed from the plant material with $3.0 \mathrm{~mL}$ petroleum ether (Sigma-Aldrich, St. Louis, MO, USA). The plant material was diluted with $2.0 \mathrm{~mL}$ ultrapure water and a $\mathrm{pH}$ above 9 was obtained by addition of $10 \%$ ammonium hydroxide (Merck KGaA, Darmstadt, Germany) solution. Metabolites were extracted twice with $2.0 \mathrm{~mL}$ dichloromethane (Rathburn Chemicals Ltd., Walkerburn, Scotland, UK). From elicited cells secondary metabolites were extracted as previously described without removing lipids with petroleum ether, plant material was diluted with $5.0 \mathrm{~mL} 10 \%$ ammonium solution and extracted with together $6.0 \mathrm{~mL}$ dichloromethane. The medium was made alkaline with 1
$\mathrm{M} \mathrm{NaOH}$ and extracted twice with $10 \mathrm{~mL}$ dichloromethane. Finally, the dichloromethane extracts were concentrated to $100 \mu \mathrm{L}$ for further analysis. For compound identification, selected samples were further trimethylsilylated with $25 \mu \mathrm{L}$ of $N$-methyl- $N$-trimethylsilyl trifluoroacetamide (Pierce, Rockford, IL, USA) at $70{ }^{\circ} \mathrm{C}$ for 20 minutes.

\section{Gas chromatography-mass spectrometry}

Commercial coniine was used to develop the Gas Chromatography-Mass Spectrometry (GC-MS) method and to determine the detection limit. A GC-MS system consisting of an Agilent 6890A GC and an Agilent 5973N MS detector (Agilent Technologies Inc., Santa Clara, CA, USA) and a Combipal automatic sampler (Varian Inc., Palo Alto, CA, USA) was used to study the elicitation extracts. Analyses were performed on a diphenyl dimethyl polysiloxane RTX-5MS (Restek, Bellefonte, PA, USA) silica capillary column $(15 \mathrm{~m} \times 250 \mu \mathrm{m}$ with a phase thickness of $0.25 \mu \mathrm{m}$ ). The oven temperature programme started from $40{ }^{\circ} \mathrm{C}(1 \mathrm{~min})$ and increased at a rate of $10^{\circ} \mathrm{C} \mathrm{min} \mathrm{mip}^{-1}$ to $270{ }^{\circ} \mathrm{C}(6 \mathrm{~min})$ resulting in a total running time of 40 minutes. Helium with a flow rate of $1.2 \mathrm{~mL} \mathrm{~min}^{-1}$ was used as the carrier gas (split ratio $15: 1$ or $20: 1$ ). Injection port temperature was $250^{\circ} \mathrm{C}$ and the injection volume $2.0 \mu \mathrm{L}$. MSD was operated in electron impact mode at $70 \mathrm{eV}$ and the data were collected in SCAN mode at a mass range of $m / z$ 40-650. The chromatograms were integrated by using MSD ChemStation software (E.02.01.1177; Agilent Technologies, Inc., Santa Clara, CA, USA). Compounds were identified on the basis of relevant literature, reference substance and spectral libraries such as Palisade Complete 600K Mass Spectral Library (Palisade Mass Spectrometry, Ithaca, NY, USA), and the NIST Mass Spectral Search 2.0 Program (The Standard Reference Data Program of the National Institute of Standards and Technology, Gaithersburg, MD, USA).

In vitro samples of A. globuligemma were analyzed and identified as above except by using an HP-5MS silica capillary column $(25 \mathrm{~m} \times 0.2 \mathrm{~mm})$ with $0.33 \mu \mathrm{m}$ phase thickness (Agilent Technologies, Inc., Santa Clara, CA, USA). The temperature program started at $50^{\circ} \mathrm{C}(1 \mathrm{~min})$ and increased at $10^{\circ} \mathrm{C} \mathrm{min}^{-1}$ up to $300^{\circ} \mathrm{C}$.

Derivatized samples ( $1 \mu \mathrm{L}$ aliquots) were analyzed in splitless mode by an Agilent GC-MS instrument consisting of a 5975MSD and a 7890A GC fitted with a $30 \mathrm{~m} \times$ $0.25 \mathrm{~mm}(0.25 \mu \mathrm{m}) \mathrm{VB}-5$ silica capillary column (Valco Instruments Co. Inch., Houston, TX, USA). The temperature program started at $50^{\circ} \mathrm{C}(1 \mathrm{~min})$ and increased at $10^{\circ} \mathrm{C} \mathrm{min} \mathrm{min}^{-1}$ up to $240{ }^{\circ} \mathrm{C}$. The data were collected at a mass range of $m / z 50-600$. Identification was performed as above. 


\section{Resullts}

\section{Surface sterilization and seed germination}

Half of the ten A. gariepensis and A. globuligemma seeds, respectively, and two of the five $A$. viguieri seeds germinated on MS medium following surface sterilization. The first seedlings emerged already within 30 days, but some seeds only germinated after four months. Mould or bacterial contaminations were not observed.

\section{Micropropagation}

Statistics indicated good predictive power of the experimental design with the parameters $\mathrm{BA}$ and NAA at levels of $0.06-0.25 \mathrm{mg} \mathrm{L}^{-1}$ and $0.1-0.4 \mathrm{mg} \mathrm{L}^{-1}$, respectively, and the time points four, five and six weeks when one outlier was omitted (Supplemental Table 1). The quality of the fit of the polynomial model equation, which is expressed as coefficient of determination $\mathrm{R}^{2}=0.952$ (> 0.5) (Umetrics, 2011) [42], indicates that $95.2 \%$ of the variability of the response is explained by the model. The predictive power was $\mathrm{Q}^{2}=0.821(>0.1)$, confirming statistical significance. Model validity was $0.982(>0.25)$ and reproducibility was $0.808(>0.5)$ [42]. Plantlets were initiated already within four weeks from the axillary buds at the base of the mother plant (Figure 3). The results of the micropropagation experiment were summarized in a $3 \mathrm{D}$ contour plot which was rendered into $2 \mathrm{D}$ representations in which the dimensions were BA, NAA and time. The highest plantlet number (5) was achieved with $\mathrm{BA}$ $0.25 \mathrm{mg} \mathrm{L}^{-1}$ and NAA $0.4 \mathrm{mg} \mathrm{L}^{-1}$ during week 4 (Figure 4). At hormone concentrations lower than $0.25 \mathrm{mg} \mathrm{L}^{-1} \mathrm{BA}$ and $0.4 \mathrm{mg} \mathrm{L}^{-1} \mathrm{NAA}$, only up to two plants were obtained (Supplemental Table 1).

Further investigation with the same model design involving higher BA and NAA levels, i.e. $0.25-4.0 \mathrm{mg} \mathrm{L}^{-1}$ and $0.4-2.0 \mathrm{mg} \mathrm{L}^{-1}$, respectively, but with the same time points as previously (four, five and six weeks) did not result in a good quality model due to low significance $\left(\mathrm{R}^{2}=\right.$

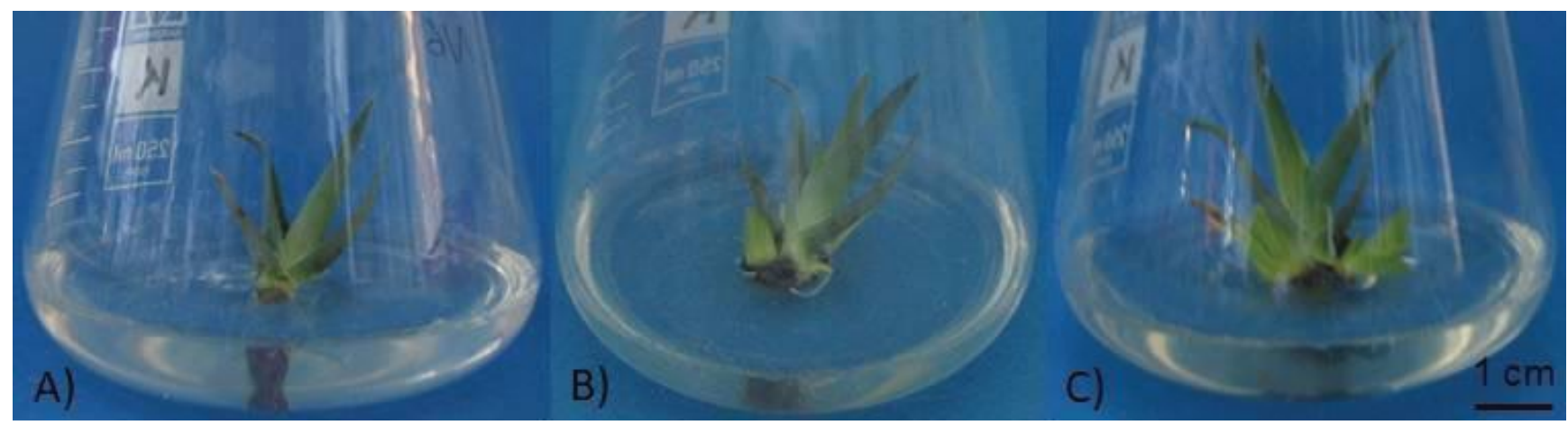

Figure 3: Typical development of a A. viguieri plant after A) 2 weeks; B) 4 weeks and C) 6 weeks.
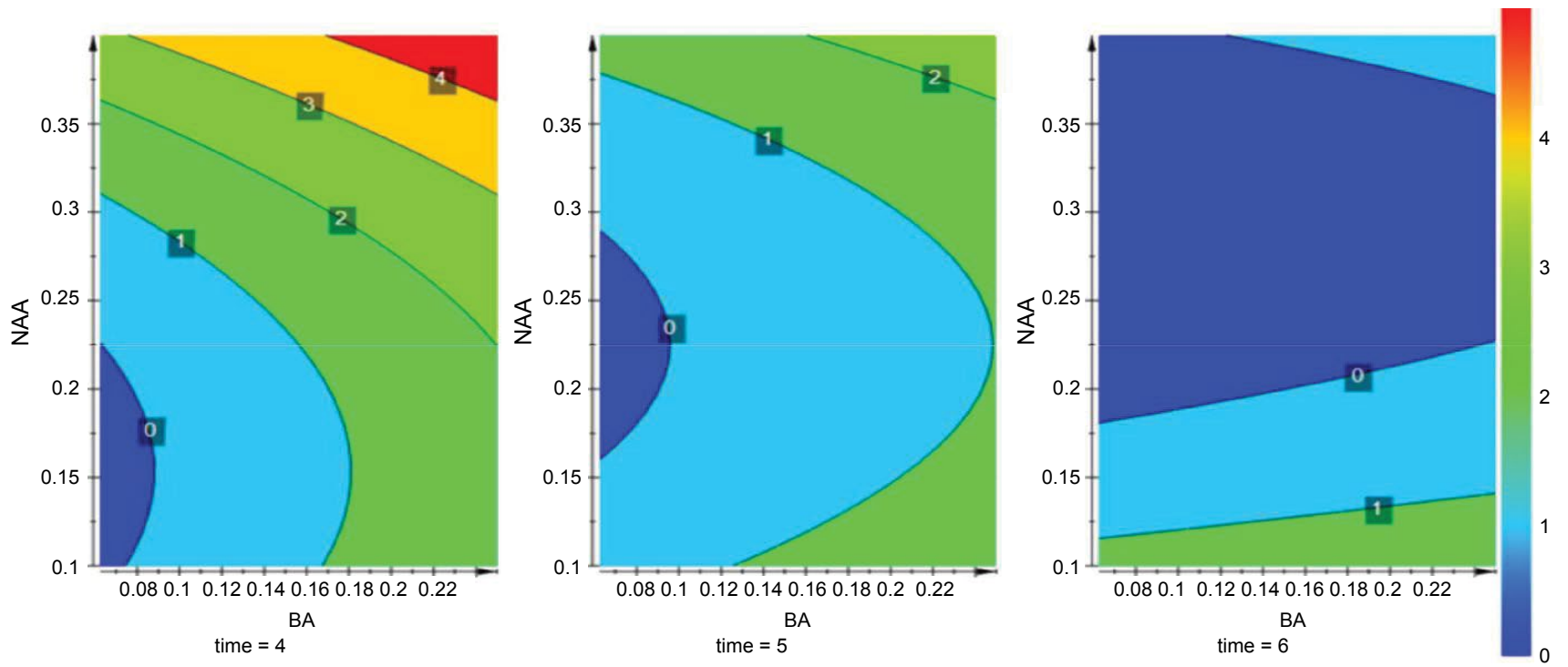

Figure 4: 2D representations of a 3D contour plot of $A$. viguieri micropropagation experiments (factors: BA, NAA and time; response: plantlet number). The color index on the right side indicates the number of plantlets generated. Altogether 17 experiments were performed. Model parameters: $R^{2}=0.952, Q^{2}=0.821$ with one outlier. The best response, five plantlets, was gained within four weeks with the hormone combination $0.25 \mathrm{mg} \mathrm{L}^{-1} \mathrm{BA}$ and $0.4 \mathrm{mg} \mathrm{L}^{-1} \mathrm{NAA}$. 
$0.267)$ and a poor predictive power $\left(\mathrm{Q}^{2}=-0.804\right)$. Therefore A. viguieri micropropagation could not be improved with higher hormone concentrations. Although a hormone combination of $4.0 \mathrm{mg} \mathrm{L}^{-1} \mathrm{BA}$ and $1.2 \mathrm{mg} \mathrm{L}^{-1} \mathrm{NAA}$ resulted in seven $A$. viguieri plantlets within four weeks and nine plantlets in six weeks (Supplemental Table 2), the plants were hyperhydrated and had poor viability.

\section{Callus initiation}

Callus induction frequency on MS medium with two different hormone regimes was evaluated 50 days after initiation. On medium containing $10.0 \mathrm{mg} \mathrm{L}^{-1} \mathrm{NAA}$ and $0.2 \mathrm{mg} \mathrm{L}^{-1} \mathrm{BA}, 16$ out of the 25 A. gariepensis explants (64\%) produced callus, whereas on medium containing $6.0 \mathrm{mg} \mathrm{L}^{-1} 2,4$-D only 1 in 20 (5\%) responded. By contrast A. viguieri explants did not produce any callus on the former medium but instead 10 out of $25(40 \%)$ initiated callus on the medium containing 2,4-D.

Initially, the medium supplements PVP, adenine and ascorbic acid were used to prevent browning. However, established calli could be maintained on medium devoid of these agents. There was also some root formation from the explants of A. gariepensis on MS with $10.0 \mathrm{mg}$ $\mathrm{L}^{-1} \mathrm{NAA}$ and $0.2 \mathrm{mg} \mathrm{L}^{-1} \mathrm{BA}$. On MS supplemented with $2.0 \mathrm{mg} \mathrm{L}^{-1} 2,4$-D calli from both species grew more vigor- ously when sub-cultured every second week. Finally, the $2,4-\mathrm{D}$ content in the medium was decreased to $1.0 \mathrm{mg} \mathrm{L}^{-1}$ and the sub-culturing to a three-week interval, without any detrimental effect (Figure 2D and Figure 2E).

\section{Growth curve}

Callus FW development was monitored for three weeks in darkness at $25^{\circ} \mathrm{C}$. Three lines of both species were selected and labeled as A-C (A. gariepensis) and $\mathrm{D}-\mathrm{E}$ (A. viguieri) based on vigorous growth and without browning or leaching of phenolics into the medium. Statistical analysis did not reveal significant differences in the original starting weights of the calli. All six callus lines grew similarly for two weeks, without statistically significant changes in callus growth except for line $\mathrm{D}$, which displayed the highest and significantly different growth compared to the other lines throughout the whole experimental period. Generally, A. viguieri grew faster than A. gariepensis (weight increase $28-86 \%$ vs. 12 $48 \%$ ). The greatest weight increase for all lines occurred during week two. Among A. gariepensis, line C exhibited the greatest weight increase, on average $38 \%$ per week, whereas line B showed the slowest overall growth with an average increase of $21 \%$. The fresh weight of the $A$. viguieri line $\mathrm{D}$ increased most, on average $72 \%$ per week.
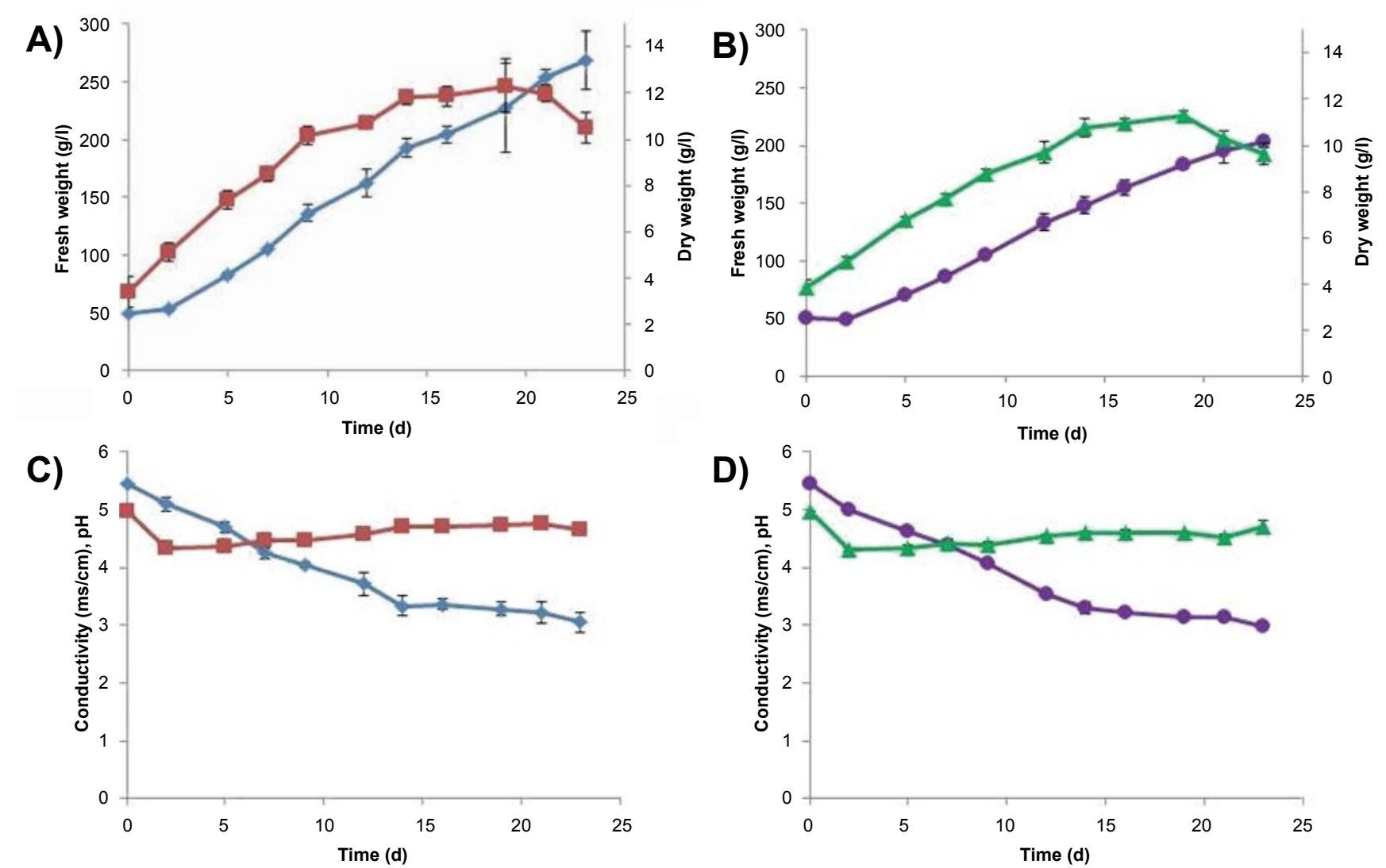

Figure 5: Biomass accumulation of $A$. gariepensis cell line $C A$ ) and $A$ viguieri cell line $D$; $C$ ) fresh weight (diamond) and dry weight (square). Changes in conductivity (circle) and $\mathrm{pH}$ (triangle) during the growth are presented for $A$ gariepensis; $\mathrm{B}$ ) and A. viguieri; D) $\mathrm{n}=3$ samples. 
Based on the initial testing of FW increase on a plate, cell lines $\mathrm{C}$ and $\mathrm{D}$ were chosen for further experimentation. For both cell lines, an inoculum of $50 \mathrm{~g} \mathrm{~L}^{-1} \mathrm{FW}$ was used in growth curves. For cell line $\mathrm{C}$ there was a two day lag period after which FW increased to its highest point, $268 \pm 25 \mathrm{~g} \mathrm{~L}^{-1}$, on day 23 (Figure $5 \mathrm{~A}$ ). DW of cell line $C$ increased until day 9 when it reached stationary phase. The maximal DW was reached on day 19 (12.3 \pm $\left.1.2 \mathrm{~g} \mathrm{~L}^{-1}\right)$ and thereafter it started to decrease. Conductivity decreased rapidly from $5.5 \mathrm{mS} \mathrm{cm}^{-1}$ (day 0 ) to $3.3 \mathrm{mS}$ $\mathrm{cm}^{-1}$ (day 14) (Figure 5B) followed by a gentle reduction to $3.0 \mathrm{mS} \mathrm{cm}^{-1}$ until the end point on day 23 . The starting $\mathrm{pH}$ (5.0) decreased rapidly to 4.3 on day 2 and then increased steadily to 4.6 on day 23 .

For cell line $\mathrm{D}$ there was a two day lag period after which FW increased to its highest point, $204 \pm 5 \mathrm{~g} \mathrm{~L}^{-1}$, on day 23 (Figure 5C). DW of cell line D increased until day 14 when it reached stationary phase. The maximal DW was reached on day $19\left(113 \pm 0.2 \mathrm{~g} \mathrm{~L}^{-1}\right)$ and thereafter it started to decrease. Conductivity decreased rapidly from $5.5 \mathrm{mS} \mathrm{cm}^{-1}$ (day 0) to $3.3 \mathrm{mS} \mathrm{cm}^{-1}$ (day 14) (Figure 5D) followed by a gentle reduction to $3.0 \mathrm{mS} \mathrm{cm} \mathrm{cm}^{-1}$ until the end point on day 23. The starting $\mathrm{pH}$ (5.0) decreased rapidly to 4.3 on day 2 and then increased steadily to 4.7 on day 23.

\section{Elicitation}

Based on growth curves of cell line $\mathrm{C}$ and $\mathrm{D}$, days 8 and 14, respectively, were chosen for the elicitations. Samples were collected on days 1, 3 and 5 after elicitation with chitosan or salicylic acid and extracts were subjected to GC-MS analysis. Cells and culture medium were separated and analyzed individually for secondary metabolites.

None of the elicited or non-elicited cell cultures contained hemlock alkaloids (Supplemental Table 3). In several samples characteristic base peaks $(\mathrm{m} / \mathrm{z})$ for coniine, $\gamma$-coniceine and/or $\mathrm{N}$-methylconiine were present, however, the concentrations were at the detection limit and the fragments, therefore, might originate from the background.

Chrysarobin and chrysophanol were detected in suspension cultures. The terpenes xanthoperol and $p$-meth8(10)-9-ol were detected in suspension cultures of cell line $\mathrm{D}$ with acetic acid and without addition, respectively. The relative amount of chrysarobin and chrysophanol in A. gariepensis cell line $\mathrm{C}$ extracts ranged from 0.2 to $1.0 \%$ and $0.13-0.31 \%$ of peak area, respectively. Chrysarobin was absent in the media of non-elicited (with acetic acid and without) and chitosan elicited samples in contrast to the salicylic acid elicited samples where its proportion was $1.18-1.32 \%$ of peak area. Chrysophanol was not present in the media. Extracts of A. gariepensis leaf and root were examined for anthraquinones, only root contained chrysophanol $0.48 \%$ of peak area.

In A. viguieri cell line $\mathrm{D}$, chrysarobin and chrysophanol were not present in media extracts without elicitor treatment. When present, the proportions of chrysarobin and chrysophanol were $0.57-1.92 \%$ and $0.09-0.65 \%$ of peak area, respectively. Chrysarobin was present in media when elicited with chitosan or salicylic acid. In addition, salicylic acid elicitation increased peak areas of both compounds and induced production of four unidentified compounds. In A. viguieri root, chrysophanol was present in $0.12 \%$ of peak area. Compound 1 was tentatively identified as a pyrrolidine with $\mathrm{MW}=305$ and a long carbon side chain (Supplemental Table 4). The mass spectra of compounds $2(\mathrm{MW}=239), 3(\mathrm{MW}=258)$ and $4(\mathrm{MW}=257)$ were compared to chrysophanol and the pattern indicated a three carbon ring structure, and thus they tentatively constitute anthraquinone type compounds. Compound 3 was found only in the media and compounds 2 and 4 were present only in the cell extract.

\section{Alkaloid composition}

GC-MS analyses of a coniine dilution series proved to have a high sensitivity (detection limit $10 \mu \mathrm{g} \mathrm{mL} \mathrm{m}^{-1}$; corresponding to $0.01 \mathrm{mg} \mathrm{g}^{-1}$ dry weight; $2.7 \%$ RSD ( $\mathrm{n}=$

Table 2: Characteristic GC-MS fragments for relevant piperidine alkaloids and anthraquinones.

\begin{tabular}{|c|c|c|c|c|c|}
\hline Compound & $\mathbf{R}_{\mathrm{t}}$ (min) & Match (\%) & CAS No. & Note & Characteristic ions (abundance \%) \\
\hline Coniine & 4.55 & $86 \%$ & $458-88-8$ & a & $127\left(\mathrm{M}^{+}, 2\right), 126(2), 98(2), 84(100), 70(4), 56(12)$ \\
\hline Y-Coniceine & 5.25 & $90 \%$ & $1604-01-9$ & $b$ & $125\left(\mathrm{M}^{+}, 13\right), 124(10), 110(35), 97(100), 82(13), 70(28)$ \\
\hline$N$-Methylconiine & 5.05 & & $35305-13-6$ & $b$ & $141\left(\mathrm{M}^{+}, 1\right), 112(1), 99(7), 98(100), 70(15)$ \\
\hline Conhydrine & 7.40 & $78 \%$ & $495-20-5$ & $a$ & $143\left(\mathrm{M}^{+}, 7\right), 114(4), 96(3), 84(100), 67(3), 56(22), 41(11)$ \\
\hline Chrysarobin & 19.44 & $97 \%$ & $491-59-8$ & $c$ & $\begin{array}{l}240\left(\mathrm{M}^{+}, 100\right), 225(29), 211(12), 197(25), 194(2), 181(17), 165 \\
(5), 152(5), 139(7), 127(2), 120(3), 115(7), 111(3), 105(3), 97 \\
(5), 89(2), 82(8), 76(4), 74(2), 69(6), 96(6), 53(2), 51(3)\end{array}$ \\
\hline Chrysophanol & 19.67 & $98 \%$ & $481-74-3$ & $c$ & $\begin{array}{l}254\left(\mathrm{M}^{+}, 100\right), 237(5), 226(11), 209(1), 197(10), 180(3), 169 \\
(3), 155(2), 152(9), 141(6), 127(5), 115(7), 105(2), 99(3), \\
90(2), 76(4), 65(2), 63(5), 57(4), 51(3), 43(5)\end{array}$ \\
\hline
\end{tabular}

adentified by comparison of retention time and mass spectra with reference material; ${ }^{b}$ Identified by comparison of spectra ([43] Palisade Complete 600K Mass Spectral Library); cldentified by comparison of spectra (NIST Mass Spectral Search 2.0 Program). 
6)). Coniine was identified based on the retention time $(4.55 \pm 0.05 \mathrm{~min})$ and the base peak $(\mathrm{m} / z \mathrm{84})$ of the commercial reference. $\gamma$-Coniceine identification was based on the mass spectral database (number 28670, Palisade Complete 600K Mass Spectral Library) and comparison to literature (Table 2) [43]. The retention time (5.05 \pm $0.05 \mathrm{~min})$ and the base peak $(\mathrm{m} / z$ 98) of $\mathrm{N}$-methylconiine were derived from reference samples (C. maculatum) naturally containing this alkaloid. $N$-methylconiine has the base peak $m / z 98$, molecular mass $m / z 141$ and typical fragments $(m / z 112,99,70)$ as reported in the literature [43]. In addition, $N$-methylconiine did not react with $N$-methyl- $N$-trimethylsilyl-trifluoroacetamide to produce trimethylsilyl derivatives, indicating a tertiary amino group. Conhydrine was present in poison hemlock which was used as reference material. Its spectrum matched the database (number 20048, Palisade Complete $600 \mathrm{~K}$ Mass Spectral Library). However, conhydrine was not detected in any studied Aloe material.

Neither the leaves of in vitro grown A. gariepensis nor any of the derived callus lines contained alkaloids, but roots contained traces of coniine and $\mathrm{N}$-methylconiine (Table 3). In vitro grown leaves of A. globuligemma contained coniine, $N$-methylconiine, and $\gamma$-coniceine, whereas roots contained only $N$-methylconiine. Leaves and roots of in vitro grown A. viguieri contained coniine, $\mathrm{N}$-methylconiine, and $\gamma$-coniceine. None of the A.viguieri callus lines contained piperidine alkaloids.

\section{Discussion}

Micropropagation protocols have hitherto only been developed for seven out of 400 Aloe species, none of which produce hemlock alkaloids. The published studies have used MS basal medium, however, there is no clear consensus on optimal hormone combinations across species. Most commonly the cytokinin BA is used in a range between 1.0 and $2.5 \mathrm{mg} \mathrm{L}^{-1}$ in combination with the auxin NAA at $0.1-1.0 \mathrm{mg} \mathrm{L}^{-1}$. Here, a micropropagation protocol for the poison aloe, A. viguieri, producing good quality plants was developed employing the experimental design software MODDE 9.0. The CCF design model indicated significance and good predictive power when the BA and NAA levels were in the range of 0.06$0.4 \mathrm{mg} \mathrm{L}^{-1}$ and $0.1-0.4 \mathrm{mg} \mathrm{L}^{-1}$, respectively, and sampling times were after four, five and six weeks. In the best scenario, i.e. at $0.25 \mathrm{mg} \mathrm{L}^{-1} \mathrm{BA}$ and $0.4 \mathrm{mg} \mathrm{L}^{-1} \mathrm{NAA}$, A. viguieri produced up to five new shoots from axillary buds of the mother rosette within four weeks. The study design, therefore, adds another suitable tool to the earlier described statistically supported micropropagation strategies for Aloe [44,45]. Although high hormone concentrations have been recommended for the micropropagation of other species, e.g. $2.0 \mathrm{mg} \mathrm{L}^{-1} \mathrm{BA}$ and $1.0 \mathrm{mg} \mathrm{L}^{-1} \mathrm{NAA}$ for $A$. arborescens [30], A. viguieri plantlets produced at 2.13 or $4.0 \mathrm{mg} \mathrm{L}^{-1} \mathrm{BA}$ and $1.2 \mathrm{mg} \mathrm{L}^{-1} \mathrm{NAA}$ were of poor quality, exhibiting hyperhydration (in older literature called vitrification) despite high abundance (up to seven shoots from the mother rosette). In this setup with BA and NAA levels between $0.25-4.0 \mathrm{mg} \mathrm{L}^{-1}$ and $0.4-2.0 \mathrm{mg}$ $\mathrm{L}^{-1}$ respectively, a robust model could not be derived [4648]. A. viguieri plants became hyperhydrated when the BA level exceeded $2.0 \mathrm{mg} \mathrm{L}^{-1}$. Hyperhydration is a physiological disorder in in vitro cultures that adversely affects growth and regeneration ability. It has been shown that more than $1.0 \mathrm{mg} \mathrm{L}^{-1} \mathrm{BA}$ triggers hyperhydricity in A. polyphylla, although inducing the highest number of shoots [44]. Abrie and van Staden [49] reported that decreasing plant hormone concentrations decreased the level of hyperhydricity in seedlings of A. polyphylla. Another crucial parameter potentially responsible for hyperhydricity is the gelling agent in the medium such as

Table 3: Piperidine alkaloids in in vitro grown plants of $A$. gariepensis, A. globuligemma and $A$. viguieri.

\begin{tabular}{|c|c|c|c|c|c|}
\hline Species & Sample & $R_{t}$ (min) & Match (\%) & Name & Area (\%) of extract ${ }^{f}$ \\
\hline \multirow[t]{3}{*}{ A. gariepensis ${ }^{d}$} & Leaf & - & - & No piperidine alkaloids & - \\
\hline & \multirow[t]{2}{*}{ Root } & 4.55 & $a$ & (Coniine) & Trace \\
\hline & & 5.05 & $a$ & (N-Methylconiine) & Trace \\
\hline \multirow[b]{4}{*}{ A. globuligemma } & \multirow[b]{3}{*}{ Leaf } & $5.85^{c}$ & $b$ & Coniine & 0.53 \\
\hline & & $6.40^{c}$ & $b$ & $N$-Methylconiine & 10.93 \\
\hline & & $6.50^{c}$ & $b$ & Y-Coniceine & 4.24 \\
\hline & Root & - & - & No piperidine alkaloids & - \\
\hline & & 4.55 & $b$ & Coniine & 4.98 \\
\hline & & 5.05 & $b$ & $N$-Methylconiine & 1.48 \\
\hline & Leaf & 5.25 & 90 & Y-Coniceine & 1.89 \\
\hline & & 4.55 & 86 & Coniine & 0.26 \\
\hline & & 5.05 & $a$ & (N-Methylconiine) & Trace \\
\hline A. viguierie & Root & 5.25 & $a$ & $(\mathrm{\gamma}$-Coniceine) & Trace \\
\hline
\end{tabular}

Traces in brackets. ${ }^{a}$ Identified on the basis of the base peak fragment present (coniine $\mathrm{m} / \mathrm{z} 84, \mathrm{Y}$-coniceine $\mathrm{m} / \mathrm{z} 97, \mathrm{~N}$-methylconiine $\mathrm{m} / \mathrm{z}$ 98); ${ }^{b}$ dentified by comparison to known spectra ([43] Palisade Complete 600K Mass Spectral Library); ${ }^{c}$ Different GC-MS analysis conditions; ${ }^{d}$ Cell lines A-C of $A$. gariepensis did not contain piperidine alkaloids; ${ }^{e}$ Cell lines $\mathrm{D}-\mathrm{F}$ of $A$. viguieri did not contain piperidine alkaloids; ${ }^{\top}$ The repeatability for coniine standard is $2.7 \% \operatorname{RSD}(n=6)$. 
gelrite which decreases the shoot multiplication rate and causes hyperhydricity in A. polyphylla [27].

Micropropagation via a callus phase has been developed for A. arborescens [30], A. ferox [32] and A. vera $[24,28,36]$. The selected micropropagation method (directly from differentiated plant material or via callus) depends on the species and the purpose [28].

Callus has been induced in several Aloe spp. for different purposes, e.g. to produce specific compounds for example aloesaponol IV [29,35]. In most studies, MS medium has been used together with a variety of different hormone combinations. Most commonly the auxins 2,4-D and NAA are used together with the cytokinins Kinetin (KIN) and BA. 2,4-D can promote callus induction [32,36,37] and cell division [28] in different Aloe species. However, in our studies only $40 \%$ of $A$. viguieri explants formed callus on MS containing $6 \mathrm{mg} \mathrm{L}^{-1} 2,4-\mathrm{D}$, the medium which Rathore, et al. [24] used for A. vera with over $75 \%$ induction rate. A. gariepensis responded better to a hormone combination of $10.0 \mathrm{mg} \mathrm{L}^{-1} \mathrm{NAA}$ and $0.2 \mathrm{mg} \mathrm{L}^{-1} \mathrm{BA}$, with $64 \%$ of explants producing callus. Yagi, et al. [29] used the same hormone combination for callus induction of $A$. vera in darkness (100\% induction rate). Overall the achieved callus induction rates for A. viguieri and A. gariepensis are in line with previously reported rates [30] for A. arborescens (27.7\% and $40 \%$ in light). However, for long-term maintenance Rathore, et al. [24] recommend lower hormone concentrations, otherwise, callus cultures may become hyperhydrated. Roy and Sarkar [36] used $1 \mathrm{mg} \mathrm{L}^{-1} 2,4-\mathrm{D}$ and $0.2 \mathrm{mg} \mathrm{L}^{-1}$ KIN, whereas we found that $1 \mathrm{mg} \mathrm{L}^{-1} 2,4-\mathrm{D}$ without KIN suffices for A. gariepensis and A. viguieri callus lines. In our study, we initially used PVP, ascorbic acid, and adenine as antioxidants to reduce the leaching of phenolic compounds and to prevent browning of tissues and surrounding culture medium. The use of PVP is based on its ability to absorb polyphenols and prevent further oxidation of phenolic compounds [50]. Roy and Sarkar [36] noted that PVP was a more efficient antioxidant than ascorbic acid and activated charcoal in preventing browning of the medium.

Previously only suspension cultures from A. saponaria [35] and A. arborescens [51] have been described. The transfer of A. viguieri and A. gariepensis callus cultures from solid to liquid medium, i.e. without a gelling agent, was unproblematic. Cell suspension cultures exhibited a typical growth curve in batch mode. Conductivity decreased in both suspension cultures due to nutrient salt consumption of the plant cells during the first 14 days. The late exponential or early stationary phase is usually considered optimal for elicitation [52]. Cell lines $\mathrm{C}$ and $D$ reached this stage on day 8 and 14, respectively.
Coniine alkaloids are interesting due to their fragmentary distribution in non-related plant taxa (dicots vs. monocots), and especially among Aloe. Their biosynthesis in Aloe is unknown, but could be similar to that in poison hemlock $[17,18,53,54]$. In previous studies Dring, et al. [11] and Nash, et al. [10] used thin layer chromatography and paper chromatography to study alkaloid contents of Aloe. They conducted ground-breaking research when they identified hemlock alkaloids from Aloe for the first time using different coloring reagents, such as Dragendorff's, and compared the findings with authentic alkaloids from C. maculatum or synthetic references using $R_{\mathrm{f}}$-values. In our study, we employed GC-MS to detect and identify alkaloids.

In contrast to the cited earlier studies $[10,11]$ reporting that $\gamma$-coniceine is absent or occurring in trace amounts, we found that the compound is the major alkaloid both in A. globuligemma and in A. viguieri, respectively. We also detected the presence of $\gamma$-coniceine in $A$. viguieri roots, using the base peak ion as a marker. Nash, et al. [10] reported that $A$. gariepensis contains $\gamma$-coniceine but in our material the alkaloid was not present in leaves. Dring, et al. [11] studied six poison aloes for their piperidine alkaloid content and report higher $\gamma$-coniceine concentrations only in A. gillilandii and A. ruspoliana. Interestingly, Blitzke, et al. [12] speculated that $\gamma$-coniceine could be a starting point for the biosynthesis of a chlorinated derivative in A. sabaea.

The presence of coniine in A. globuligemma [10] and A. viguieri leaves [11] was confirmed, but additionally, coniine was also found in A. viguieri roots. To our knowledge, we here report the occurrence of $\mathrm{N}$-methylconiine in the genus Aloe for the first time. $\mathrm{N}$-methylconiine is present in the unrelated plant, poison hemlock [55] and a similar alkaloid, $\mathrm{N}, \mathrm{N}$-dimethylconiine, has been reported from A. sabaea [12]. We detected $N$-methylconiine in A. globuligemma leaves and roots, and in A. viguieri leaves. Based on the detected ion $\mathrm{m} / \mathrm{z} 98$ it is possible that $\mathrm{N}$-methylconiine is also present in low amounts in A. gariepensis and A. viguieri roots. Poison aloes contain higher amounts of alkaloids than poison hemlock [56], but the latter exhibits a greater diversity [57].

Different growth conditions or genotypes could explain why conhydrine was absent in A. gariepensis and A. globuligemma, in contrast to the results of Nash, et al. [10] who found it in the leaves of both species. Detection problems can be ruled out since we clearly detected conhydrine in C. maculatum reference samples. It has been observed that alkaloid content in poison hemlock and $A$. globuligemma depends on the population, weather, location, season, size and age of the plant $[10,58]$. A certain strain of poison hemlock, for example, produces conhydrine as a major alkaloid in outdoor conditions but pseudoconhydrine in the greenhouse [59]. 
Strikingly, callus lines never contained piperidine alkaloids neither untreated nor when elicited with chitosan or salicylic acid. Similar observations were made by Nétien and Combet [60] and Meier, et al. [37] with green poison hemlock callus lines grown in light. Roberts [61] suggested that coniine alkaloid biosynthesis occurs in the chloroplasts localized in the green aerial parts of poison hemlock. In Conium specialized ducts, called 'vittae', specifically, accumulate coniine and might be involved in alkaloid biosynthesis [58,62]. In completely undifferentiated calli the biosynthetic capacity might, therefore, be blocked. The synthetic plant hormone, 2,4$\mathrm{D}$, could be another reason for the absence of hemlock alkaloids in Aloe callus. There are reports that 2,4-D generally exhibits an inhibitory role in secondary metabolism $[63,64]$. It can either alter the alkaloid profile e.g. in Leucojum aestivum callus [65], or inhibit the production altogether as in the case of tobacco alkaloids [63] and terpenoid indole alkaloids [66].

In contrast to alkaloids, chrysophanol and chrysarobin were clearly observed in cell cultures and growth media. Chrysophanol, an anthraquinone, is known to occur in Rheum, Rumex, Rhamnus, Senna species [9] and in Asphodelaceae [67]. It is also known from A. vera and exhibits anti-inflammatory activity [38]. The compound is also present in roots of $A$. gariepensis and A. viguieri. Chrysarobin, an anthrone, is found from the stem of Cassia singueana [68] and Chinese rhubarb [69]. There is no previous report of this compound in Aloe. Elicitation with chitosan increased relative peak areas of chrysophanol and chrysarobin. The most noticeable effect was triggered with salicylic acid for both cell lines. Peak areas of both compounds increased several times and production of three additional compounds increased. In A. garienpensis the relative concentrations of chrysophanol are lower in the calli than in the root but for A. viguieri there was an up to six fold increase of chrysophanol concentration when non-elicited root is compared to calli elicited with salicylic acid. Lee, et al. [38] elicited root culture of $A$. vera with salicylic acid and noticed a 5-13 fold increase in chrysophanol production. They also noticed that salicylic acid treatment increased expression of OKS transcripts leading to anthraquinone production. Therefore, besides missing specialized tissue, an alternative explanation for the absence of piperidine alkaloids in callus could be substrate competition (i.e. for malonyl-CoA) of OKS and the yet to be identified type III PKS responsible for alkaloid formation.

In conclusion, we studied three Aloe species, A. gariepensis, A. globuligemma and A. viguieri, which were chosen based on previous reports on their alkaloid content. Micropropagation of A. viguieri on MS medium containing $0.25 \mathrm{mg} \mathrm{L}^{-1} \mathrm{BA}$ and $0.4 \mathrm{mg} \mathrm{L}^{-1} \mathrm{NAA}$ led to five high-quality plantlets per mother rosette within four weeks. Lower hormone levels produced fewer plantlets, whereas higher hormone concentrations produced more but hyperhydrated plantlets. Here we report for the first time $N$-methylconiine from Aloe and $\gamma$-coniceine from A. globuligemma. Explants of A. viguieri and A. gariepensis generated callus on MS medium supplemented with $6.0 \mathrm{mg} \mathrm{L}^{-1} 2,4-\mathrm{D}$ and with a combination of $10.0 \mathrm{mg} \mathrm{L}^{-1}$ $\mathrm{NAA}$ and $0.2 \mathrm{mg} \mathrm{L}^{-1} \mathrm{BA}$, respectively. Additives (PVP, ascorbic acid and adenine) were initially used in callus induction medium to prevent toxic effects of leached compounds. However, established calli of both species have been maintained for over two years on $1.0 \mathrm{mg} \mathrm{L}^{-1}$ 2,4-D on MS without additives. Aloe callus can be grown in suspension culture without any visible deterioration such as hyperhydration. Neither callus cultures of $A$. gariepensis nor of $A$. viguieri contained hemlock alkaloids with or without elicitation with salicylic acid or chitosan. Anthraquinones chrysophanol and chrysarobin were present in examined cell and media extracts. Elicitation with salicylic acid increased the concentration of chrysophanol.

\section{Conflict of Interest}

The authors declare that the research was conducted in the absence of any commercial or financial relationships that could be construed as a potential conflict of interest.

\section{Author Contributions}

$\mathrm{HH}, \mathrm{STH}, \mathrm{TS}-\mathrm{L}, \mathrm{HR}$ planned the experiments; $\mathrm{HH}$, TS-L performed the experiments; HH, STH, TS-L, HR analyzed the data; $\mathrm{HH}, \mathrm{STH}, \mathrm{HR}$ wrote the paper.

\section{Funding}

This research was supported by funding from Academy of Finland (grant 138808 to HR), Finnish Doctoral Program in Plant Science, Oskar Öflunds Stiftelse, Eteläsuomalaisten ylioppilaiden säätiö and the Otto A. Malm Foundation (all to $\mathrm{HH}$ ).

\section{Acknowledgments}

We thank Teemu Teeri for discussions, Kaarina Viljanen for GC-MS analysis, and Riitta Puupponen-Pimiä, Riitta Julkunen-Tiitto and Kirsi-Marja Oksman-Caldentey for commenting on the manuscript. A draft of this manuscript has been part of a dissertation [57].

\section{References}

1. Murashige $T$, Skoog $F(1962)$ A revised medium for rapid growth and bioassays with tobacco tissue cultures. Physiologia Plantarum 15: 473-497.

2. Viljoen AM, van Wyk BE, van Heerden FR (1998) Distribution and chemotaxonomic significance of flavonoids in Aloe (Asphodelaceae). PI Syst Evol 211: 31-42. 
Citation: Hotti H, Häkkinen ST, Laakso TS, et al. (2017) Polyketide-Derived Alkaloids and Anthraquinones in Aloe Plants and Cell Cultures. J Plant Biotechnol Res 1(1):1-15

3. Loots du T, van der Westhuizen FH, Botes L (2007) Aloe ferox leaf gel phytochemical content, antioxidant capacity, and possible health benefits. J Agric Food Chem 55: 68916896.

4. Smith $\mathrm{T}$, Smith $\mathrm{H}$ (1851) On aloin: the cathartic principles of aloes. Mon J Med Sci 12: 127-131.

5. Mizuuchi Y, Shi SP, Wanibuchi K, et al. (2009) Novel type III polyketide synthases from Aloe arborescens. FEBS J 276: 2391-2401.

6. Malik EM, Müller CE (2016) Anthraquinones as pharmaceutical tools and drugs. Med Res Rev 36: 705-748.

7. Abe I, Oguro S, Utsumi Y, et al. (2005) Engineered biosynthesis of plant polyketides: chain length control in an octaketide-producing plant type III polyketide synthase. J Am Chem Soc 127: 12709-12716.

8. Reynolds T (1997) Comparative chromatographic patterns of leaf exudate components from Aloe section Pachydendron Haw. Botanical Journal of the Linnean Society 125: 45-70.

9. Steglich W, Fugmann B, Lang-Fugmann S (2000) RÖMPP Encyclopedia natural products. ( $1^{\text {st }}$ edn), Georg Thieme Verlag, Germany.

10. Nash RJ, Beaumont J, Veitch NC, et al. (1992) Phenylethylamine and piperidine alkaloids in Aloe species. Planta Med 58: 84-87.

11. Dring JV, Nash RJ, Roberts MF, et al. (1984) Hemlock alkaloids in Aloes. Occurrence and distribution of $\mathrm{y}$-coniceine. Planta Med 50: 442-443.

12. Blitzke T, Porzel A, Masoud M, et al. (2000) A chlorinated amide and piperidine alkaloids from Aloe sabaea. Phytochemistry 55: 979-982.

13. Mody NV, Henson R, Hedin PA, et al. (1976) Isolation of the insect paralysing agent coniine from Sarracenia flava. Experientia 32: 829-830.

14. Hotti H, Gopalacharyulu P, Seppänen-Laakso T, et al. (2017) Metabolite profiling of the carnivorous pitcher plants Darlingtonia and Sarracenia. PLoS One 12: e0171078.

15. Leete $E$ (1963) The biosynthesis of coniine from four acetate units. J Am Chem Soc 85: 3523-3524.

16. Leete $E$ (1964) Biosynthesis of the hemlock alkaloids. The incorporation of acetate-1-C ${ }^{14}$ into coniine and conhydrine. J Am Chem Soc 86: 2509-2513.

17. Hotti H, Seppänen-Laakso T, Arvas M, et al. (2015) Polyketide synthases from poison hemlock (Conium maculatum L.). FEBS J 282: 4141-4156.

18. Roberts MF (1971) The formation of $y$-coniceine from 5-ketooctanal by a transaminase of Conium maculatum. Phytochemistry 10: 3057-3060.

19. Roberts MF (1977) Purification and properties of L-alanine:5-ketooctanal aminotransferase from Conium maculatum. Phytochemistry 16: 1381-1386.

20. Roberts MF (1975) y-Coniceine reductase in Conium maculatum. Phytochemistry 14: 2393-2397.

21. Drummond RB, Gelfand M, Mavi S (1975) Medicinal and other uses of succulents by the Rhodesian African. Excelsa 5: $51-56$
22. Parry O, Matambo C (1992) Some pharmacological actions of aloe extracts and Cassia abbreviata on rats and mice. Cent Afr J Med 38: 409-414.

23. Reynolds T (2005) Hemlock alkaloids from Socrates to poison aloes. Phytochemistry 66: 1399-1406.

24. Rathore MS, Chikara J, Shekhawat NS (2011) Plantlet regeneration from callus cultures of selected genotype of Aloe vera $\mathrm{L}$. An ancient plant for modern herbal industries. Appl Biochem Biotechnol 163: 860-868.

25. Grace OM (2011) Current perspectives on the economic botany of the genus Aloe L. (Xanthorrhoeaceae). South African Journal of Botany 4: 980-987.

26. Gantait S, Mandal N, Das PK (2011) In vitro accelerated mass propagation and ex vitro evaluation of Aloe vera $\mathrm{L}$. with aloin content and superoxide dismutase activity. Nat Prod Res 25: 1370-1378.

27. Ivanova M, van Staden J (2011) Influence of gelling agent and cytokinins on the control of hyperhydricity in Aloe polyphylla. Plant Cell, Tissue and Organ Culture 104: 13-21.

28. Velcheva M, Faltin Z, Vardi A, et al. (2010) Aloe vera transformation: the role of Amberlite XAD-4 resin and antioxidants during selection and regeneration. In Vitro Cellular \& Developmental Biology - Plant 46: 477-484.

29. Yagi A, Hine N, Asai M, et al. (1998) Tetrahydroanthracene glucosides in callus tissue from Aloe barbadensis leaves. Phytochemistry 47: 1267-1270.

30. Bedini C, Caccia R, Triggiani D, et al. (2009) Micropropagation of Aloe arborescens Mill: A step towards efficient production of its valuable leaf extracts showing antiproliferative activity on murine myeloma cells. Plant Biosyst 143: 233-240.

31. Tatsuo K, Amano M (1985) Callus formation in stamens of Aloe bellatura. Ann Tsukuba Bot Gard 3: 19-26.

32. Racchi ML (1988) Using in vitro culture to study the biosynthesis of secondary products in Aloe ferox. Riv Agr Subtrop Trop 82: 707-714

33. Ramsay MM, Gratton J (2000) Propagation of Aloe polyphylla Schönl. ex Pillans from callus derived from leaf tissue. Botanic Gardens Micropropagation News 2: 61-64.

34. Groenewald EG, Koeleman A, Wessels DCJ (1975) Callus formation and plant regeneration from seed tissue of Aloe pretoriensis Pole Evans. Zeitschrift für Pflanzenphysiologie 75: $270-272$.

35. Yagi A, Shoyama Y, Nishioka I (1983) Formation of tetrahydroanthracene glucosides by callus tissue of Aloe saponaria. Phytochemistry 22: 1483-1484.

36. Roy SC, Sarkar A (1991) In vitro regeneration and micropropagation of Aloe vera L. Scientia Horticulturae 47: 107-113.

37. Meier P, Hotti H, Rischer H (2015) Elicitation of furanocoumarins in poison hemlock (Conium maculatum L.) cell culture. Plant Cell, Tissue and Organ Culture 123: 443-453.

38. Lee YS, Ju HK, Kim YJ, et al. (2013) Enhancement of anti-inflammatory activity of Aloe vera adventitious root extracts through the alteration of primary and secondary metabolites via salicylic acid elicitation. PLoS One 8: e82479.

39. Carew DP, Bainbridge T (1976) Biotransformations with plant tissue cultures. Lloydia 39: 147-149. 
Citation: Hotti H, Häkkinen ST, Laakso TS, et al. (2017) Polyketide-Derived Alkaloids and Anthraquinones in Aloe Plants and Cell Cultures. J Plant Biotechnol Res 1(1):1-15

40. Sevón N, Varjonen T, Hiltunen R, et al. (1992) Effect of sucrose, nitrogen and copper on the growth and alkaloid production of transformed root cultures of Hyoscyamus muticus. Planta Med 58: 609-610.

41. Häkkinen ST, Moyano E, Cusidó RM, et al. (2005) Enhanced secretion of tropane alkaloids in Nicotiana tabacum hairy roots expressing heterologous hyoscyamine-6 $\beta$-hydroxylase. J Exp Bot 56: 2611-2618.

42. Umetrics (2011) Design for experiments. Umetrics academy: Training in multivariate technology, IID1066. Umetrics $A B$, Sweden.

43. Holstege DM, Galey FD, Johnson B, et al. (1996) Determination of alkaloid exposure in a model ruminant (goat) using a multiresidue screening method. J Agric Food Chem 44: 2310-2315.

44. Chukwujekwu JC, Fennell CW, van Staden J (2002) Optimisation of the tissue culture protocol for the endangered Aloe polyphylla. S Afr J Bot 68: 424-429.

45. Liao Z, Chen M, Tan F, et al. (2004) Micropropagation of endangered Chinese aloe. Plant Cell, Tissue and Organ Culture 76: 83-86.

46. Leshem B, Werker E, Shalev DP (1988) The effect of cytokinins on vitrification in melon and carnation. Ann Bot 62: 271-276.

47. Tsay H (1998) Effects of medium composition at different recultures of on vitrification of carnation (Dianthus caryophyllus) in vitro shoot proliferation. Acta Hort 461: 243-249.

48. Thomas P, Mythili JB, Shivashankar KS, et al. (2000) Explant, medium and vessel aeration affect the incidence of hyperhydricity and recovery of normal plantlets in triploid watermelon. The Journal of Horticultural Science and Biotechnology 75: 19-25.

49. Abrie AL, van Staden J (2001) Micropropagation of the endangered Aloe polyphylla. Plant Growth Regulation 33: 19-23.

50. Sathyanarayana BN, Varghese DB (2007) Plant tissue culture: Practices and new experimental protocols. I.K. International Publishing House Pvt. Ltd., India.

51. Liu Y, Takatsuki H, Yoshikoshi A, et al. (2003) Effects of ultrasound on the growth and vacuolar $\mathrm{H}^{+}$-ATPase activity of Aloe arborescens callus cells. Colloids and Surfaces B: Biointerfaces 32: 105-116.

52. Baldi A, Srivastava AK, Bisaria VS (2009) Fungal elicitors for enhanced production of secondary metabolites in plant cell suspension cultures. In: Varma A, Kharkwal AC, Soil Biology 18-Symbiotic Fungi. Springer-Verlag, Germany, 373-380.

53. Leete E, Olson JO (1970) 5-Oxo-octanoic acid and 5-oxo-octanal, precursors of coniine. J Chem Soc D 16511652.

54. Leete E, Olson JO (1972) Biosynthesis and metabolism of the hemlock alkaloids. J Am Chem Soc 94: 5472-5477.
55. Cromwell BT (1956) The separation, micro-estimation and distribution of alkaloids of hemlock (Conium maculatum L.). Biochem J 64: 259-266.

56. López TA, Cid MS, Bianchini ML (1999) Biochemistry of hemlock (Conium maculatum L.) alkaloids and their acute and chronic toxicity in livestock. A review. Toxicon 37: 841865.

57. Hotti H (2016) The killer of Socrates exposed-Coniine in the plant kingdom [Dissertation]. VTT Technical Research Centre of Finland Ltd., Finland.

58. Fairbairn JW, Challen SB (1959) The alkaloids of hemlock (Conium maculatum L.). Distribution in relation to the development of the fruit. Biochem J 72: 556-561.

59. Leete E, Adityachaudhury N (1967) Biosynthesis of the hemlock alkaloids - II. The conversion of $\mathrm{y}$-coniceine to coniine and $\Psi$-conhydrine. Phytochemistry 6: 219-223.

60. Nétien G, Combet J (1971) Etude comparative dans la composition chimique des cultures de tissus de Conium maculatum cultivées in vitro. I. Variation des substances azotees. Paris Soc Biol Compt Rend 165: 103-107.

61. Roberts MF (1981) Enzymatic synthesis of y-coniceine in Conium maculatum chloroplasts and mitochondria. Plant Cell Reports 1: 10-13.

62. Corsi G, Biasci D (1998) Secretory Structures and localization of alkaloids in Conium maculatum L. (Apiaceae). Annals of Botany 81: 157-162.

63. Tabata M, Hiraoka N (1976) Variation of alkaloid production in Nicotiana rustica callus cultures. Physiologia Plantarum 38: 19-23.

64. Stalman M, Koskamp AM, Luderer R, et al. (2003) Regulation of anthraquinone biosynthesis in cell cultures of Morinda citrifolia. J Plant Physiol 160: 607-614.

65. Ptak A, El Tahchy A, Skrzypek E, et al. (2013) Influence of auxins on somatic embryogenesis and alkaloid accumulation in Leucojum aestivum callus. Cent Eur J Biol 8: 591599.

66. Rischer H, Orešič M, Seppänen-Laakso T, et al. (2006) Gene-to-metabolite networks for terpenoid indole alkaloid biosynthesis in Catharanthus roseus cells. Proc Natl Acad Sci U S A 103: 5614-5619.

67. Bringmann $\mathrm{G}$, Noll T, Rischer $\mathrm{H}$ (2002) In vitro germination and establishment of tissue cultures of Bulbine caulescens and of two Kniphofia species (Asphodelaceae). Plant Cell Reports 21: 125-129.

68. Ibrahim MA, Koorbanally NA, Islam S (2013) In vitro anti-oxidative activities and GC-MS analysis of various solvent extracts of Cassia sangueana parts. Acta Pol Pharm 70: 709-719.

69. Han C, Wang J, Li Y, et al. (2013) In vitro antimicrobial activity and effect on $\mathrm{E}$. coli integrity of cinnamon essential oil and rhubarb ethanol extract. Food Science and Technology Research 19: 1155-1163. 
Citation: Hotti H, Häkkinen ST, Laakso TS, et al. (2017) Polyketide-Derived Alkaloids and Anthraquinones in Aloe Plants and Cell Cultures. J Plant Biotechnol Res 1(1):1-15

Supplemental Table 1: A. viguieri plantlet formation with different BA, NAA combinations and treatment durations.

\begin{tabular}{|l|l|l|l|l|}
\hline BA $\left.\mathbf{( m g ~ L} \mathbf{~}^{-1}\right)$ & NAA $\left(\mathbf{m g ~ L}^{-1}\right)$ & Time $\mathbf{~ ( w e e k s )}$ & Number of plantlets & Data included/excluded \\
\hline 0.06 & 0.1 & 4 & 0 & Included \\
\hline 0.25 & 0.1 & 4 & 2 & Included \\
\hline 0.06 & 0.4 & 4 & 0 & Excluded \\
\hline 0.25 & 0.4 & 4 & 5 & Included \\
\hline 0.06 & 0.1 & 6 & 1 & Included \\
\hline 0.25 & 0.1 & 6 & 2 & Included \\
\hline 0.06 & 0.4 & 6 & 0 & Included \\
\hline 0.25 & 0.4 & 6 & 0 & Included \\
\hline 0.06 & 0.25 & 5 & 0 & Included \\
\hline 0.25 & 0.25 & 5 & 1 & Included \\
\hline 0.16 & 0.1 & 5 & 1 & Included \\
\hline 0.16 & 0.4 & 5 & 2 & Included \\
\hline 0.16 & 0.25 & 4 & 1 & Included \\
\hline 0.16 & 0.25 & 6 & 0 & Included \\
\hline 0.16 & 0.25 & 5 & 1 & Included \\
\hline 0.16 & 0.25 & 5 & 0 & Included \\
\hline 0.16 & 0.25 & 5 & 0 & Included \\
\hline
\end{tabular}

Supplemental Table 2: $A$. viguieri plantlet formation with different BA and NAA combinations. Results were recorded after 4,5 and 6 weeks.

\begin{tabular}{|l|l|l|l|l|}
\hline \multicolumn{5}{|c|}{ Number of plantlets } \\
\hline BA $\mathbf{( m g ~ L - 1 )}$ & NAA $\left(\mathbf{m g ~ L}^{-1}\right)$ & $\mathbf{4}$ weeks & $\mathbf{5}$ weeks & $\mathbf{6}$ weeks \\
\hline 0.25 & 0.4 & 0 & 0 & 0 \\
\hline 0.25 & 2 & 0 & 0 & 0 \\
\hline 4 & 0.4 & 1 & 1 & 1 \\
\hline 4 & 2 & 0 & 1 & 1 \\
\hline 2.13 & 0.4 & 2 & 2 & 2 \\
\hline 2.13 & 2 & 3 & 4 & 5 \\
\hline 0.25 & 1.2 & 2 & 2 & 2 \\
\hline 4 & 1.2 & 7 & 7 & 9 \\
\hline 2.13 & 1.2 & 1 & 8 & 8 \\
\hline 2.13 & 1.2 & 2 & 2 & 2 \\
\hline 2.13 & 1.2 & 0 & 3 & 3 \\
\hline & & & & \\
\hline
\end{tabular}


Citation: Hotti H, Häkkinen ST, Laakso TS, et al. (2017) Polyketide-Derived Alkaloids and Anthraquinones in Aloe Plants and Cell Cultures. J Plant Biotechnol Res 1(1):1-15

Supplemental Table 3: The presence of base peak fragments of hemlock alkaloids in elicited samples. The ions were present in trace amounts.

\begin{tabular}{|c|c|c|c|c|c|c|c|c|}
\hline \multirow[b]{3}{*}{ Cell line } & \multirow[b]{3}{*}{ Elicitor } & \multirow{3}{*}{$\begin{array}{l}\text { Days after } \\
\text { elicitation }\end{array}$} & \multicolumn{6}{|l|}{ Time point } \\
\hline & & & \multicolumn{2}{|l|}{$4.55 \mathrm{~min}$} & \multicolumn{2}{|l|}{$5.05 \mathrm{~min}$} & \multicolumn{2}{|l|}{$5.25 \mathrm{~min}$} \\
\hline & & & Cells $m / z$ & Liquid $m / z$ & Cells $m / z$ & Liquid $m / z$ & Cells $m / z$ & Liquid $m / z$ \\
\hline \multirow{12}{*}{$\begin{array}{l}\text { Aloe } \\
\text { gariepensis } \\
\text { line C }\end{array}$} & \multirow{3}{*}{$\begin{array}{l}\text { Without } \\
\text { addition }\end{array}$} & 1 & 84 & 84 & 98 & 98 & - & 97 \\
\hline & & 3 & 84 & 84 & - & 98 & - & 97 \\
\hline & & 5 & 84 & 84 & - & 98 & - & 97 \\
\hline & \multirow[b]{3}{*}{ Acetic acid } & 1 & 84 & 84 & - & - & - & 97 \\
\hline & & 3 & 84 & - & - & 98 & - & 97 \\
\hline & & 5 & 84 & 84 & - & - & - & 97 \\
\hline & \multirow[b]{3}{*}{ Chitosan } & 1 & - & 84 & - & - & 97 & 97 \\
\hline & & 3 & 84 & 84 & - & - & - & 97 \\
\hline & & 5 & - & 84 & 98 & - & 97 & 97 \\
\hline & \multirow[b]{3}{*}{ Salicylic acid } & 1 & 84 & 84 & 98 & 98 & 97 & 97 \\
\hline & & 3 & - & 84 & - & 98 & - & 97 \\
\hline & & 5 & - & 84 & - & 98 & - & 97 \\
\hline \multirow{12}{*}{$\begin{array}{l}\text { Aloe viguieri } \\
\text { line } D\end{array}$} & \multirow{3}{*}{$\begin{array}{l}\text { Without } \\
\text { addition }\end{array}$} & 1 & - & 84 & - & 98 & - & 97 \\
\hline & & 3 & 84 & 84 & - & 98 & - & 97 \\
\hline & & 5 & - & 84 & - & 98 & - & 97 \\
\hline & \multirow[b]{3}{*}{ Acetic acid } & 1 & - & 84 & - & 98 & - & 97 \\
\hline & & 3 & - & 84 & - & 98 & 97 & 97 \\
\hline & & 5 & - & 84 & 98 & 98 & 97 & 97 \\
\hline & \multirow[b]{3}{*}{ Chitosan } & 1 & 84 & 84 & - & 98 & - & 97 \\
\hline & & 3 & 84 & 84 & - & 98 & - & 97 \\
\hline & & 5 & - & 84 & - & 98 & 97 & 97 \\
\hline & \multirow[b]{3}{*}{ Salicylic acid } & 1 & - & 84 & - & 98 & 97 & 97 \\
\hline & & 3 & 84 & 84 & - & 98 & - & 97 \\
\hline & & 5 & 84 & 84 & - & 98 & 97 & 97 \\
\hline
\end{tabular}

Explanation: - not present.

Supplemental Table 4: Mass spectra of compounds 1-4 from elicited suspension cultures of cell lines C (Aloe gariepensis) and $\mathrm{D}$ (Aloe viguieri).

\begin{tabular}{|l|l|l|}
\hline Name & $\mathbf{R}_{\mathbf{t}}(\mathbf{m i n})$ & Mass spectra (abundance \%) \\
\hline & & $\begin{array}{l}305\left(\mathrm{M}^{+}, 9\right), 290(2), 276(3), 262(12), 248(23), 234(7), 220(5), 208(13), 194(26), 180(4), 168(5), \\
154(19), 149(1), 140(8), 124(5), 112(17), 98(100), 85(68), 79(18), 69(17), 67(36), 57(13), 55 \\
(39), 44(16), 41(35)\end{array}$ \\
\hline Compound 1 & 19.518 & $\begin{array}{l}239\left(\mathrm{M}^{+}, 100\right), 224(32), 210(9), 196(15), 180(4), 165(11), 152(4), 139(3), 126(1), 115(3), 105(4), \\
96(1), 90(3), 83(3), 77(3), 69(2), 63(57), 57(2), 51(2), 41(2)\end{array}$ \\
\hline Compound 2 & 21.049 & $\begin{array}{l}258\left(\mathrm{M}^{+}, 100\right), 240(46), 229(9), 225(24), 212(14), 201(30), 197(14), 183(5), 173(10), 165(7), \\
155(11), 141(7), 127(17), 115(17), 99(10), 91(4), 85(22), 77(6), 71(26), 65(2), 57(29), 43(19)\end{array}$ \\
\hline Compound 3 & 21.325 & $\begin{array}{l}257\left(\mathrm{M}^{+}, 100\right), 239(47), 228(10), 224(30), 210(9), 196(15), 181(2), 173(3), 165(8), 152(6), 139 \\
(4), 128(10), 115(10), 105(3), 98(4), 90(6), 83(5), 77(6), 69(5), 63(3), 57(4), 43(5)\end{array}$ \\
\hline
\end{tabular}

